\title{
Keeping it Clean: Cleaning the Kitchen Stove, Range Top, and Oven 1
}

Mary N. Harrison ${ }^{2}$

A clean kitchen is a "must." It is very important to the health of your family.

\section{Cleaning Your Stove}

When people cook, foods splatter. If not cleaned up, these spills will attract insects. They can also turn to acid and damage the porcelain enamel of the range. Regular cleaning of your stove will eliminate these problems as well as prevent burned food odors and the risk of fire.

\section{Supplies Needed:}

- Ammonia or commercial oven cleaner

- Abrasive cleaner or baking soda

- Rubber gloves

- Rags or a sponge

- Scraper

- Dishwashing detergent

\section{Range Tops}

\section{Daily}

- First, avoid spills. Don't cook foods so fast they bubble over or splatter. Be careful when moving food into and out of pans.

- Make wiping up the range cooktop a regular part of your cleanup each day. Pay attention to areas where foods were cooked and clean under grids of gas ranges or the drip pans under electrical units if there were spills.

\section{Weekly}

-Wipe the surfaces of the range or cooktop with a rag. Rinse often in soapy water.

- If there are hard-to-remove spots, use a rounded knife or wooden scraper to remove burned or dried food. Then scrub stain with baking soda and a rag.

- Remove drip pans from under the burners and soak in the sink. Scrub and dry. Clean under the drip pan with soap and water. You may cover the drip pan with aluminum foil. Fold foil over the

1. This document is FCS5232-05, one of a series of the Family Youth and Community Sciences Department, Florida Cooperative Extension Service, Institute of Food and Agricultural Sciences, University of Florida. Original publication date June 2002. Revised December 2005. Visit the EDIS Web Site at http://edis.ifas.ufl.edu.

2. Mary N. Harrison, professor, Department of Family, Youth and Community Sciences, Cooperative Extension Service, Institute of Food and Agricultural Sciences, University of Florida, Gainesville, 32611.

The Institute of Food and Agricultural Sciences (IFAS) is an Equal Opportunity Institution authorized to provide research, educational information and other services only to individuals and institutions that function with non-discrimination with respect to race, creed, color, religion, age, disability, sex, sexual orientation, marital status, national origin, political opinions or affiliations. U.S. Department of Agriculture, Cooperative Extension Service, University of Florida, IFAS, Florida A. \& M. University Cooperative Extension Program, and Boards of County Commissioners Cooperating. Larry Arrington, Dean 
pan and punch a hole in the foil at the location of the hole in the drip pan. Put pan back in place. Make sure the foil does not touch the burner or heating element.

\section{Ovens}

\section{Daily}

- Prevent the need for frequent oven cleaning by avoiding oven spills. Use the right size pans to keep foods from cooking over. If there is a spill, wipe it up as soon as the oven cools.

- When broiling, help avoid splattering by carefully following the instructions. If there is splattering, wipe the oven out.

- Spilled foods burn again each time you turn the oven on. It is hard to clean out of the oven and it also makes foods you are cooking taste odd.

\section{Monthly, or as needed}

To Clean Ovens by Hand:

- Move oven racks to the sink. Clean them with sudsy water and steel wool to remove burned-on food.

- Soften baked-on spots with a rag soaked with ammonia. Let soak for 30 minutes, and then wipe out the oven with a rag dampened with water. Rinse often.

- The alternative is to use a commercial oven cleaner.

\section{Self-cleaning Ovens:}

- Self-cleaning ovens can be cleaned by following directions that come with the range.

- Never use oven cleaners on self-cleaning or continuous cleaning ovens. Cleaners can damage those kinds of ovens. Use ammonia.

\section{Problem Solving}

- A gas range: The flame should be blue; a yellow flame indicates incomplete combustion. Make sure burners are clean and not clogged.

- An electric range: If the element will not heat it may need to be replaced. The electrical elements can burn out.

- Glass ceramic cooktops: Cracking can happen when a large utensil is touching a piece of metal trim. Be careful in placing utensils on the cooktop.

- Oven thermostat: If an oven takes too long to cook or overcooks foods in the recommended time, the thermostat may need to be replaced. Oven temperature will normally cycle about 25 degrees above and below the set temperature. Check the temperature with an oven thermometer.

- If any part of a range is not working, check first to see if the circuit breaker for the range is tripped. 